\title{
The Effect of Frozen Storage on Serum Insulin-Like Activity
}

\author{
By Lawrence Power, Gerard Collin de l'Hortet and Jerome Conn
}

With the technical assistance of John Shuman

\begin{abstract}
Storage of serum at $-20 \mathrm{C}$. is associated with an increase of its insulin-like activity in as short a period as 3 weeks. Separated serum proteins also show an increase under similar conditions. This is of practical importance for workers
\end{abstract}

who make such measurements. The possibility that these observations result from alterations in a serum insulin moiety is discussed. (Metabolism 15: No. 2, February, 103-106, 1966)

W

HEN BLOOD from human subjects is assayed for insulin and for insulin activity, values obtained with biologic methods are distinctly higher than with immunologic methods. ${ }^{1-5}$ Until further studies reconcile this discrepancy, the nature and significance of the activity measured with the bioassays will remain uncertain. Realizing this, most investigators using bioassays express their results in terms of insulin-like activity (ILA). Use of the term implies the net biologic effect of insulin, including its inhibitors and its accelerators. Factors that are neither insulin nor require it for their activity are also included and may be important biologically.

Conditions that increase levels of serum ILA in vitro must be eliminated if comparable results with the same assay system are to be obtained in different laboratories. For this reason a study of the effect of standard conditions of freezer storage on serum ILA and serum protein ILA was undertaken. It has been said that serum ILA remains constant during months of frozen storage, ${ }^{6}$ but the present study indicates that under these conditions ILA increases significantly in both serum and serum protein fractions over periods of 3 weeks and 3 months.

\section{Materials AND Methods}

Large samples of venous blood were drawn from 6 young fasting adults with normal carbohydrate tolerance. The specimens were allowed to clot at room temperature for $\mathbf{4 5}$ minutes, then centrifuged at $2 \mathrm{C}$. for 20 minutes. Serum was separated and stored at $-20 \mathrm{C}$. within 10 minutes of removal from the refrigerated centrifuge.

Aliquots of serum from each subject were stored undisturbed at -20 . C. for 1 week,

The Department of Internal Medicine (Division of Endocrinology and Metabolism and the Metabolism Research Unit), University of Michigan Medical Center, Ann Arbor, Michigan.

Supported in part by Public Health Service Grants Nos. AM-00888 and TI-AM5001.

Received for publication Oct. 27, 1965.

LaWrence Power, M.D.: Associate Professor of Internal Medicine, Wayne State College of Medicine, Detroit, Mich. Gerard Collin de L'Hortet, M.D.: Hospital de Diabetologie, Vals-Les-Baines, Ardeche, France. Jеrome W. Conn, M.D.: Professor of Internal Medicine, University of Michigan, Ann Arbor, Mich. 

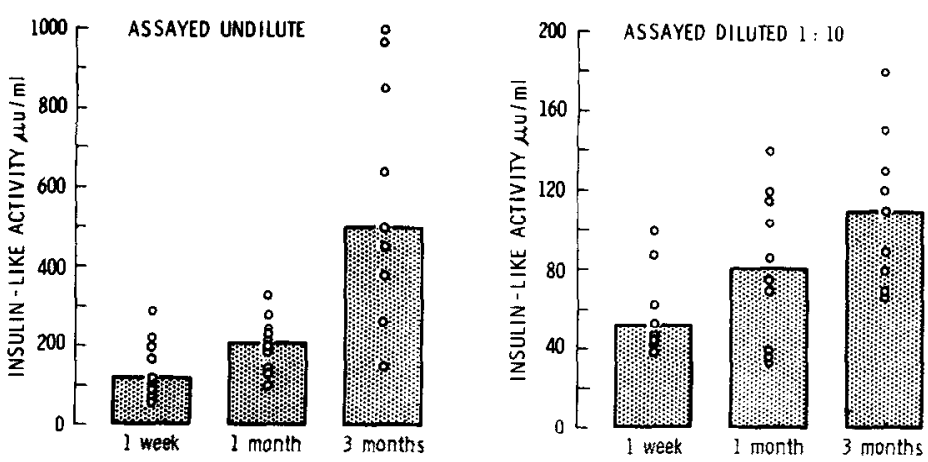

Fig. 1.-The effect of storage at $-20 \mathrm{C}$. on serum insulin-like activity. Six fasting normal subjects.

1 month and 3 months prior to assay. In addition, 2 days before assay, an aliquot of serum of each subject was removed and fractionated into albumin and globulin components by dialysis against ammonium sulfate. 7 These fractions were assayed for their insulin-like activity at the same time as the companion aliquots of stored serum.

A third study involved the albumin-globulin fractionation of a large aliquot of scrum from each subject 2 days after the original venous blood collection. This provided sufficient albumin and globulin from each subject to allow study of the effect of storage at $-20 \mathrm{C}$. on the ILA of isolated serum protein.

Assays for insulin-like activity were performed with a modification of the epididymal fat pad method. ${ }^{3}$ Serum was assayed undiluted and after dilution with Krebs bicarbonate buffer to a concentration of one part serum to 9 parts buffer. The separated proteins were dissolved for assay in freshly-prepared Krebs buffer: the albumin fraction at a concentration of $15 \mathrm{mg} . / \mathrm{ml}$. and the globulin fraction at $2 \mathrm{mg} . / \mathrm{ml}$. Where the quantity of a specimen permitted. more than one assay was performed and recorded separately in the data.

\section{RESUlts}

Serum ILA was found to increase progressively during frozen storage. Insulin-like activity of undiluted serum rose from a median of $120 \mu \mathrm{U} / \mathrm{ml}$. at one week to a median of $500 \mu \mathrm{U} / \mathrm{ml}$. at 3 months (Fig. 1). Increases began during the first month of storage and could be demonstrated, although to a reduced extent, in specimens diluted for assay (Fig. 1).

Separated serum proteins similarly stored, also increased their detectable concentration of ILA (Fig. 2). The increase occurred whether the protein was separated before storage or following storage. The predominant concentration of ILA in the globulin fraction has been described ${ }^{8}$ and is seen again in the present studies.

\section{Discussion}

It has been reported that serum insulin-like activity is increased by storage, ${ }^{*}$ but the observation was unaccompanied by data and did not indicate the extent of the increase. The present work demonstrates a fourfold increase over 14 weeks under standard freezer-storage conditions. Investigators reporting values for insulin-like activity should in the future include mention of the duration of storage of their specimens prior to assay. 


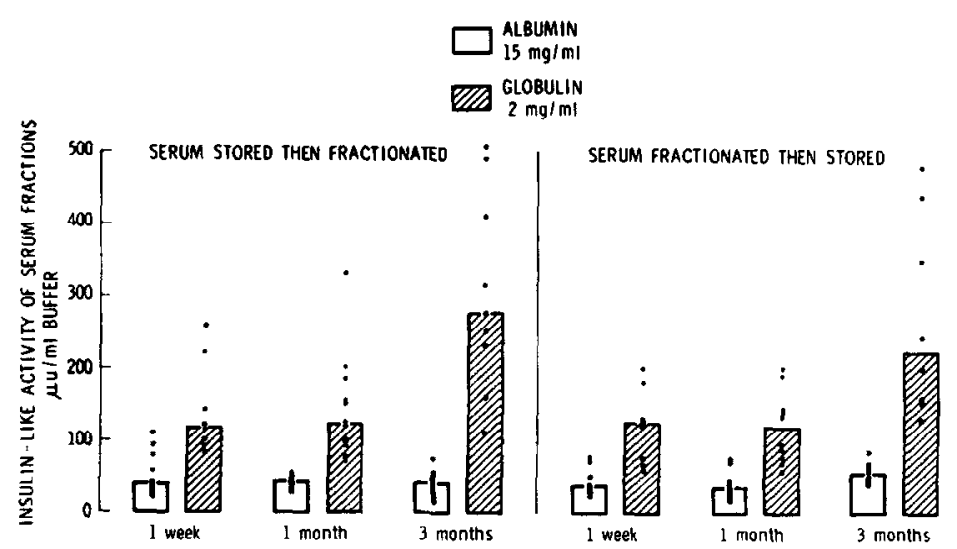

Fig. 2.-The effect of storage at $-20 \mathrm{C}$. on the insulin-like activity of serum proteins from 6 fasting normal subjects.

To explain these observations, several speculative considerations present themselves. The first is the possibility that disintegrating, inactive macromolecules release products into frozen serum that possess insulin-like activity. This is not a remote possibility since serum cannot be considered to be thoroughly frozen until $-50 \mathrm{C}$. has been reached. ${ }^{\circ}$ It has also been shown that proteins such as antibody globulins deteriorate readily at $-20 \mathrm{C} .{ }^{10}$ If such a process were responsible for the observations recorded here, the peptide fragments with insulin-like activity in vitro would probably have little biologic significance in vivo. They would be artifactual denaturation products. On the other hand, if the denaturation process involved a macromolecular serum insulin moiety, the active subfragments yielded could hold much physiologic interest. In the same general category another possibility is that a normal, inactive form of serum insulin undergoes spontaneous activation during storage at $-20 \mathrm{C}$., perhaps through deterioration of a serum inhibitor. Obviously, much work must be done before the reported facts can be explained.

Failure of the ILA of stored serum diluted for assay, to increase in the same proportion as stored serum that is undiluted for assay is of interest but difficult to interpret. Dilution does itself lead to an increase of ILA, as does frozen storage, but whether or not the ILA released by both processes is derived from a common precursor cannot be determined from the data.

\section{REFERENCES}

1. Sheps, M. C., Nickerson, R. J., Dagenais, Y. M., Steinke, J., Martin, D. B., and Renold, A. E.: Measurement of small quantities of insulin-like activity using rat adipose tissue. II. Evaluation of performance. J. Clin. Invest. 39: 1499, 1960.

2. Seltzer, H. S., and Smith, W. L.: Plasma insulin activity after glucose. An index of insulogenic reserve in normal and diabetic man. Diabetes
8:417, 1959

3. Power, L., Reyes-Leal, B., and Conn, J. W.: Serum insulin-like activity in genetic and experimental diabetes mellitus. Metabolism 13:1297, 1964.

4. Yalow, R. S., and Berson, S. A.: Immunoassay of endogenous plasma insulin in man. J. Clin. Invest. 39:1157, 1960.

5. Hales, C. N., and Randle, P. J.: Immunoassay of insulin with insulin- 
antibody precipitate. Biochem. J. 88: 137, 1963.

6. Steinke, J.: Personal communication, 1963.

7. Power, L., Lucas, C., and Conn, J. W.: A globulin system from human serum that augments the activity of crystalline insulin on the epididymal fat pad. deficiency in diabetes mellitus. Metabolism 14:104, 1965.

8. - Reyes-Leal, B., and Conn, J. W.: A comparison of insulin-like activity in the serum proteins of normal subjects and diabetic patients. Diabetes 14:
$71,1965$.

9. Lyngsoe, J.: The insulin-like activity in serum determined by the rat epididymal fat method. I. Normal values in undiluted and diluted serum, and the effect of ingestion of glucose. Acta med. Scandinav. 171:365, 1962.

10. Rey, L. R.: Thermal analysis of eutetics in freezing solutions. Ann. New York Acad. Sci. 85:510, 1960.

11. VanArsdel P. P.. Jr., and Sells, C. J.: Antigenic histamine release from passively sensitized human leukocytes. Science 141:1190, 1963. 